\title{
Direct-Driven Interior Magnet Permanent Magnet Synchronous Motors for a Full Electric Sports Car
}

\author{
Janne Nerg, Senior Member, IEEE, Marko Rilla, Vesa Ruuskanen, Juha Pyrhönen, Member, IEEE, \\ and Sami Ruotsalainen
}

\begin{abstract}
The design process of direct-driven permanent magnet synchronous machines (PMSMs) for a full electric $4 \times 4$ sports car is presented. The rotor structure of the machine consists of two permanent magnet layers embedded inside the rotor laminations thus resulting in some inverse saliency, where the q-axis inductance is larger than the d-axis one. An integer slot stator winding was selected to fully take advantage of the additional reluctance torque. The performance characteristics of the designed PMSMs were calculated by applying a twodimensional finite element method. Cross-saturation between the d- and q-axes was taken into account in the calculation of the synchronous inductances. The calculation results are validated by measurements.
\end{abstract}

Index Terms - Analysis, design, electric propulsion, electric vehicle, finite element analysis, internal permanent magnet (PM) motor, PM synchronous machine, PM motors, synchronous machines.

\section{NOMENCLATURE}

$\begin{array}{ll}B_{\mathrm{r}} & \text { Remanent flux density } \\ i_{\mathrm{d}}, & \text { Direct-axis current } \\ i_{\mathrm{q}} & \text { Quadrature-axis current } \\ i_{\mathrm{S}} & \text { Stator current vector } \\ L_{\mathrm{d}} & \text { Direct-axis synchronous inductance } \\ L_{\mathrm{q}} & \text { Quadrature-axis synchronous inductance } \\ q & \text { Number of stator slots per pole and phase } \\ Q_{\mathrm{s}} & \text { Number of stator slots } \\ T & \text { Temperature } \\ u_{\mathrm{s}} & \text { Stator voltage vector } \\ \gamma & \text { Current angle } \\ \delta & \text { Load angle } \\ \varphi & \text { Angle between current and voltage vectors }\end{array}$

Manuscript received November 15, 2012; revised January 16, 2013; accepted February 13, 2013.

J. Nerg, V. Ruuskanen, and J. Pyrhönen are with LUT-Energy, Lappeenranta University of Technology, P.O. Box 20, 53851 Lappeenranta, Finland (e-mail: nerg@lut.fi; vesa.ruuskanen@lut.fi; juha.pyrhonen@lut.fi).

M. Rilla is with Visedo Oy, Tuotantokatu 2, 53850 Lappeenranta, Finland (e-mail: marko.rilla@visedo.fi).

S. Ruotsalainen is with Helsinki Metropolia University of Applied Sciences, P.O. Box 4000, 00079 Metropolia, Finland (e-mail: sami.ruotsalainen@metropolia.fi).

Copyright (c) 2009 IEEE. Personal use of this material is permitted. However, permission to use this material for any other purposes must be obtained from the IEEE by sending a request to pubs-permissions@ieee.org.

$\begin{array}{ll}\sigma_{\text {Ftan }} & \text { Tangential stress } \\ \psi_{\mathrm{d}} & \text { Direct-axis flux linkage } \\ \psi_{\mathrm{PM}} & \text { Flux linkage caused by permanent magnets } \\ \psi_{\mathrm{q}} & \text { Quadrature-axis flux linkage } \\ \psi_{\mathrm{s}} & \text { Stator flux linkage }\end{array}$

\section{INTRODUCTION}

G NERGY efficiency and environmental protection are gaining importance in modern automotive applications. As the greenhouse gas emissions are directly related to vehicle emissions, government agencies and different classification organizations have developed more stringent standards for fuel consumption and emissions. This has led to the development of environmentally friendly, energy efficient electric and hybrid electric vehicles [1]-[4].

The research in the field of electric machines in vehicle propulsion has been intense over the past few years. Different machine types have been introduced and their performances have been compared. According to the results found for instance in [5]-[13], the most popular electric machine type studied for vehicle propulsion is the permanent magnet synchronous machine (PMSM). Its electrical efficiency and torque density are highest of the present-day electrical machines, and while not suffering from a multiple pole design, it is well suitable for direct-driven applications. Furthermore, by selecting a machine topology where permanent magnets are embedded inside the rotor structure, there are no problems related to the magnet fastening, the magnets are effectively shielded from the demagnetizing armature reaction field, and furthermore, because of the inverse saliency, an additional benefit can be reached in terms of reluctance torque.

The design process of a traction machine differs from the design process of a traditional industrial machine, where the machine is designed to mostly operate at a nominal speed and torque. In traction machines, the maximum torque is required during acceleration taking place at a low rotational speed. Therefore, in traction applications, a machine is required, the efficiency of which is high in constant speed operation and which is capable of producing high torque during acceleration. To achieve a high efficiency in constant speed operation, the machine should not be heavily overdimensioned. This means that the machine should be designed closer to the needed average power instead of the peak power requirement. A high 
torque demand in the acceleration affects the electromagnetic design in such a way that the magnetic circuit of the stator must be dimensioned loose enough to tolerate the high electrical loading without being saturated [14]. In practice, this is done by considering a low value of magnetic flux density in the stator teeth in the nominal point operation, thus preventing saturation under high current-boost-caused armature reaction. A high current density in the acceleration also sets demands for the thermal design of the motor. This is because the stator winding Joule losses in the acceleration are considerably higher than the losses in the nominal torque operation. Thus, the heat transfer from the stator coils to the frame and the final cooling medium must be studied with care.

This paper is an extension of [15], presenting the design process of interior magnet PMSMs for a $4 \times 4$ full electric sports car Electric RaceAbout (E-RA) [16]. Each of the machines are comprised of an integer slot winding stator and a rotor where two layers of shaped Neodymium-Iron-Boron $(\mathrm{NdFeB})$ permanent magnets are embedded inside the laminated rotor structure. The machine performance was calculated by the finite element analysis (FEA). The calculation of the cross-saturated synchronous inductances is presented and the reluctance torque production capability of the designed PMSM as a function of load angle is discussed. The calculated motor loss distribution and efficiencies in different load conditions are discussed. Measured data from a road-legal electric vehicle lap record on Nürburgring Nordschleife in September 2011 are presented.

\section{DESIGN SPECIFICATION}

The full electric $4 \times 4$ sports car has a direct four-wheel drive (4WD) with four PMSMs. Every wheel has a similar directdriven PMSM of its own, and therefore, no mechanical gearboxes are needed. Four direct-drive motors were adopted because their control is implemented in the traction control system of the vehicle. This enables multifunctional control of the drive dynamics both at traction and braking torques as well as wheel-specific braking and anti-slip control. The mechanical connection of the PMSM to the wheel is achieved with a drive shaft illustrated in Fig. 1.

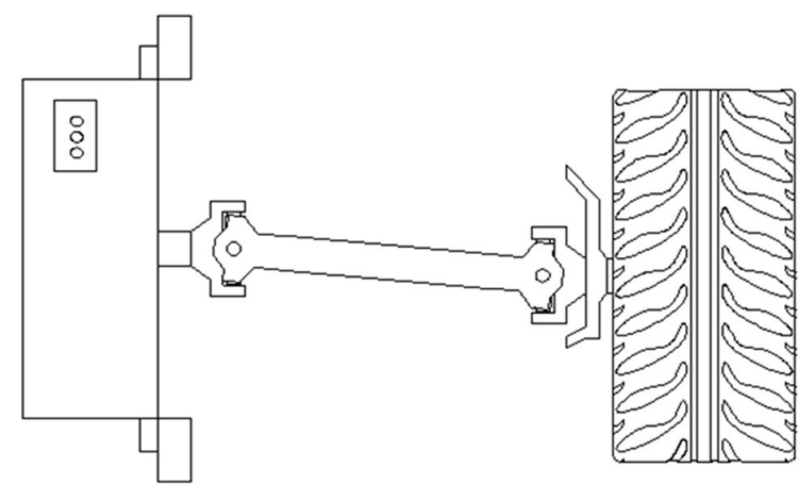

Fig. 1. Mechanical connection of the PMSM to the wheel in a direct drive propulsion system.

The dimensional envelope of the PMSMs was based on the actual space available in the car chassis. The maximum active length of the PMSM including the end windings was $200 \mathrm{~mm}$ and the maximum stator external diameter was $380 \mathrm{~mm}$. The average torque and rotation speed were adopted from a drive cycle of specified sports car track data. According to the supplied data, the nominal power of one PMSM is $25 \mathrm{~kW}$ and the nominal speed is set to $1000 \mathrm{rpm}$. Therefore, the nominal torque is $240 \mathrm{Nm}$. The desired acceleration time from zero to $100 \mathrm{~km} / \mathrm{h}$ is 6 seconds corresponding to the pull-out torque demand of $800 \mathrm{Nm}$. The maximum continuous speed of the electric vehicle is set to $200 \mathrm{~km} / \mathrm{h}$, and because of the wheel diameter of $0.64 \mathrm{~m}$, it occurs at $1665 \mathrm{rpm}$. The maximum rotation speed of the machine was set to $2000 \mathrm{rpm}$. The maximum battery voltage is $415 \mathrm{~V}$ corresponding to the maximum root-mean-square (RMS) fundamental line-to-line voltage of $293 \mathrm{~V}$. The maximum battery power is $400 \mathrm{~kW}$, which means that the maximum input for each of the machines is $100 \mathrm{~kW}$.

In the machine design, a rotor construction where two layers of shaped $\mathrm{NdFeB}$-magnets are embedded inside the laminated rotor structure was selected as a base solution. The structure of one pole of the designed PMSM is depicted in Fig. 2. Owing to the use of two layers of permanent magnets, the rotor construction is similar to the one used in the permanentmagnet-assisted synchronous reluctance machine presented, for example, in [17]-[18], but without flux barriers. A similar rotor structure is also presented in the case of PMSM in [19], but with flux barriers. There were three practical reasons for this selection: First, in an embedded magnet design there are no manufacturing problems related to the magnet fastening. Second, the magnets are safe from the demagnetizing armature reaction in field weakening and in the case of a two- or threephase short circuit. Third, inverse saliency provides additional reluctance torque. Furthermore, the embedded magnet rotor structure allows some field weakening capability. In order to achieve a sinusoidal magnetic flux distribution in the air gap, the rotor pole lamination is shaped in the quadrature axis direction. The drawback of using an embedded two-layer magnet structure in the rotor is the fact that a high-remanence magnet material is needed because of the high stray fluxes in the magnet sides. The shaping of the rotor lamination in the quadrature-axis direction helps to minimize the stray flux in the sides of the upper magnets. It must also be noticed that the shaping of the quadrature-axis direction of the rotor pole lamination decreases the reluctance torque production capability by approx. 15 percent. At the same time, because of the lower stray flux, the total torque achieved with the shaped rotor is about 10 percent higher compared with the rotor construction that has no shaping in the quadrature-axis direction.

To take advantage of the reluctance torque production capability and to achieve short end-windings, the stator winding type was selected to be a two-layer integer slot winding with one slot per pole and phase $q=1$. This is justified by the fact that even if the manufacturing process of fractional slot concentrated windings, especially with open stator slots, is much cheaper compared with the manufacturing 
of integral slot windings, the reluctance torque production capability is relatively small with fractional slot concentrated windings as presented in [5] and [11].

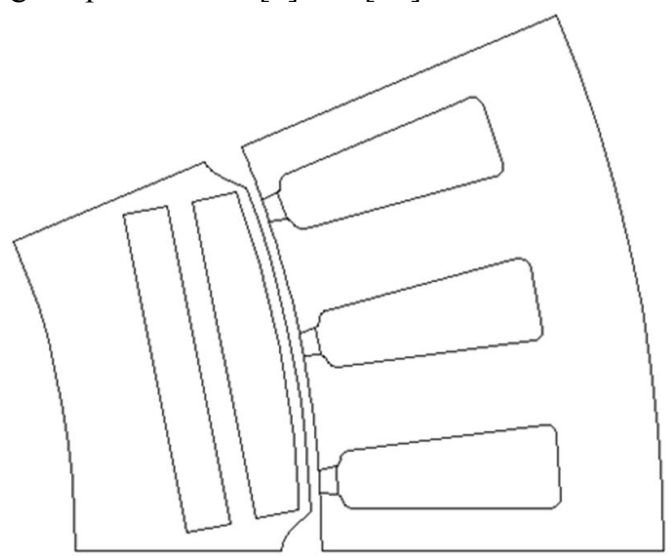

Fig. 2. Schematic of one pole of the designed PMSM.

The cooling of the PMSMs is carried out by combining air cooling in the air gap region with liquid cooling in the stator frame. The tangential stress $\sigma_{\text {Ftan }}$ for the machine was selected to $\sigma_{\text {Ftan }}=36 \mathrm{kPa}$ leading to a rotor outer diameter of $284.2 \mathrm{~mm}$ and an active stack length of $65 \mathrm{~mm}$. The electrical steel lamination used both in the stator and rotor stacks was M270$50 \mathrm{~A}$. In order to minimize the end effects and the resulting loss in the no-load voltage, the rotor stack is made $3 \mathrm{~mm}$ longer than the stator stack [20]-[21]. The physical air gap length in the direct-axis was selected to $1.4 \mathrm{~mm}$, and the rotor pole structure was shaped in such a way that the maximum value of the quadrature-axis physical air gap is $5.5 \mathrm{~mm}$.

To make the stator structure light, the machine was decided to be built with a high pole number. A high pole number allows a light iron core, because the number of flux paths for the main flux increase linearly as the pole number increases. As the number of pole pairs has an inversely proportional effect on the required stator yoke height, the number of pole pairs was chosen to be eight, thus leading to a structure where the maximum stator external diameter was not exceeded. Furthermore, the space needed for the two-layer windings in the axial direction is close to the pole pitch of the machine. Therefore, a $q=1$ machine competes, to some extent, with the tooth coil machines $(q \leq 0.5)$ in the end winding length. With the rotor outer diameter of $284.2 \mathrm{~mm}$, the pole pitch is about $56 \mathrm{~mm}$, which yields a total active part length of $177 \mathrm{~mm}$. The number of stator slots per pole and phase is $q=1$, and therefore, the number of stator slots is $Q_{\mathrm{s}}=48$. The stator tooth width is chosen to be $11.6 \mathrm{~mm}$, keeping the flux density of the stator tooth body at $1.5 \mathrm{~T}$ in normal operation. Because the largest polarization at the $50 \mathrm{~Hz}$ excitation given by the manufacturer for the selected M270-50A sheet is around 1.7 $\mathrm{T}$, which can be considered a practical flux density limit for the given sheet grade, there is a $0.2 \mathrm{~T}$ margin for the flux density limit to allow space in the stator tooth body for flux boost in the acceleration. Lower flux density values can be used in the dimensioning of the stator tooth, but this causes additional weight and results in less slot volume. It must be borne in mind that the actual flux density values can easily exceed $2 \mathrm{~T}$, especially on the corners of the rotor edge and the upper magnet edge. In order to obtain realistic results, the magnetization curve of the magnetic core material must be extended to quite a heavy saturation region. The stator slot height is $32.5 \mathrm{~mm}$.

In order to reduce cogging torque and load torque ripple with the integer slot winding, the stator stack was skewed by one stator slot pitch. It should also be mentioned that skewing and shaping of the rotor pole effectively reduce the local radial force, which could result in acoustic noise and vibration problems especially in machines with a high pole number. In the nominal point operation, the maximum value of this local radial force is calculated to be $313.8 \mathrm{~N}$. The main parameters of the PMSM are presented in Table I.

TABLE I

MAIN PARAMETERS OF THE DESIGNED PMSM

\begin{tabular}{ll} 
Number of pole pairs & 8 \\
Number of phases & 3 \\
Number of stator slots & 48 \\
Stator tooth width & $11.6 \mathrm{~mm}$ \\
Stator slot height & $32.5 \mathrm{~mm}$ \\
Stator outer diameter & $380 \mathrm{~mm}$ \\
Stator bore diameter & $287 \mathrm{~mm}$ \\
Active stator stack length & $65 \mathrm{~mm}$ \\
Active rotor stack length & $68 \mathrm{~mm}$ \\
Rotor outer diameter & $284.2 \mathrm{~mm}$ \\
d-axis air gap length (min) & $1.4 \mathrm{~mm}$ \\
q-axis air gap length (max) & $5.5 \mathrm{~mm}$ \\
Permanent magnet type & Neorem $753 \mathrm{a}$ \\
Remanent flux density of PM @ $20^{\circ} \mathrm{C}$ & $1.28 \mathrm{~T}$ \\
Length of the upper magnet & $43.9 \mathrm{~mm}$ \\
Length of the lower magnet & $43.9 \mathrm{~mm}$ \\
Thickness of the upper magnet (max. value) & $8.5 \mathrm{~mm}$ \\
Thickness of the lower magnet & $6 \mathrm{~mm}$ \\
Number of slots per pole per phase & 1 \\
Number of conductors in one slot & 8 \\
Number of conductors series per phase & 64 \\
Stator winding connection & Star \\
Rated line to line voltage & $165.4 \mathrm{~V}$ \\
Rated phase current & $100 \mathrm{~A}$ \\
Rated frequency & $133.3 \mathrm{~Hz}$ \\
Rated power & $25 \mathrm{~kW}$ \\
Total active mass & $38.1 \mathrm{~kg}$ \\
\hline
\end{tabular}

\section{FInITE ELEMENT ANALYSIS}

\section{A. Back EMF}

The calculated phase and line-to-line no-load voltages at the rotation speed of $1000 \mathrm{rpm}$ are presented in Fig. 3. The calculation was performed using the skew module of Flux2D/3D software package. The axial length of the machine was divided into five layers, and the total skew was one stator slot pitch. In the calculation, the PMSM was considered to be at the temperature $T$ of $20{ }^{\circ} \mathrm{C}$ corresponding to the PM remanent flux density $B_{\mathrm{r}}$ of $1.28 \mathrm{~T}$. The calculated line-to-line no-load voltage RMS value was $155.6 \mathrm{~V}$, and the measured value in identical thermal conditions was $154.3 \mathrm{~V}$. This means that with a full battery, the maximum rotation speed of the PMSM without field weakening is $1900 \mathrm{rpm}$ with cold magnets $\left(T=20^{\circ} \mathrm{C}\right)$ and $2000 \mathrm{rpm}$ with hot magnets $(T=80$ ${ }^{\circ} \mathrm{C}$ and $\left.B_{\mathrm{r}}=1.2 \mathrm{~T}\right)$. In practice, with an almost empty battery 
and a high torque, the field weakening starts at about 1400 rpm.

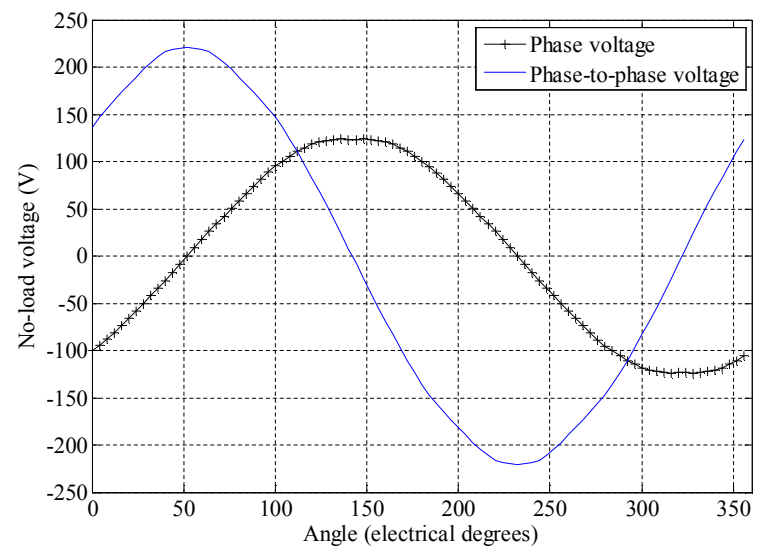

Fig. 3. Calculated phase (dotted line) and phase-to-phase (solid line) no-load voltages at the speed of $1000 \mathrm{rpm}$.

\section{B. Synchronous Inductances}

For a proper PMSM control, the PMSM synchronous inductances must be known as accurately as possible over the whole operation range of the machine [22]. In the designed interior magnet PMSM, the direct- and quadrature-axis synchronous inductances depend on both the direct- and quadrature-axis current components, and therefore, crosssaturation must be taken into account in the synchronous inductance calculations. In order to take the cross-saturation between the $\mathrm{d}$ - and q-axes into account in the synchronous inductance calculation, the PMSM synchronous inductances are calculated in a locked-rotor position for different sets of direct- and quadrature axis currents $\left(i_{\mathrm{d}}\right.$ and $\left.i_{\mathrm{q}}\right)$ by the static FEM. The direct- and quadrature-axis flux linkages $\psi_{\mathrm{d}}$ and $\psi_{\mathrm{q}}$ are calculated for each $i_{\mathrm{d}}$ and $i_{\mathrm{q}}$ combination from phase flux linkages by applying a Park transformation as presented in [23]. The cross-saturated incremental synchronous inductances $L_{\mathrm{d}}$ and $L_{\mathrm{q}}$ are calculated as

$$
\begin{gathered}
L_{\mathrm{d}}=\left.\frac{\partial \psi_{\mathrm{d}}\left(i_{\mathrm{d}}, i_{\mathrm{q}}\right)}{\partial i_{\mathrm{d}}} \approx \frac{\Delta \psi_{\mathrm{d}}}{\Delta i_{\mathrm{d}}}\right|_{i_{\mathrm{q}}=\text { constant }} \\
L_{\mathrm{q}}=\left.\frac{\partial \psi_{\mathrm{q}}\left(i_{\mathrm{d}}, i_{\mathrm{q}}\right)}{\partial i_{\mathrm{q}}} \approx \frac{\Delta \psi_{\mathrm{q}}}{\Delta i_{\mathrm{q}}}\right|_{i_{\mathrm{d}}=\text { constant }} .
\end{gathered}
$$

It must be noticed that the flux linkage caused by the permanent magnets must be extracted from the direct-axis flux linkage in (1). Synchronous inductances calculated by (1) and (2) do not contain the end-winding leakage inductance, and thus, it must be calculated analytically using the equations found in the literature and included in (1) and (2). The calculated d-axis synchronous inductance as a function of dand q-axis currents is shown in Fig. 4.

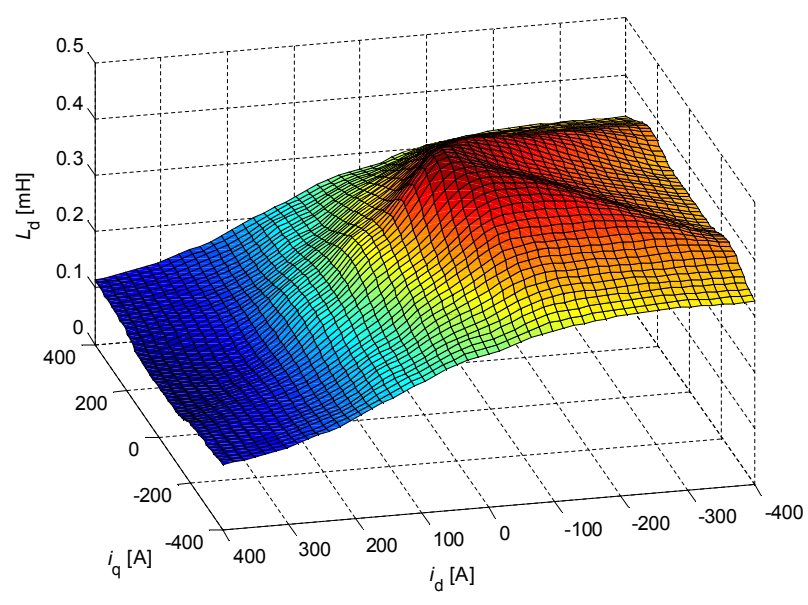

Fig. 4. Calculated direct-axis incremental synchronous inductance as a function of direct- and quadrature-axis currents with $\Delta i_{\mathrm{d}}=20 \mathrm{~A}$.

When investigating Fig. 4, we see that the incremental behavior of $L_{\mathrm{d}}$ is symmetrical with the positive and negative values of the quadrature-axis current. Saturation of $L_{\mathrm{d}}$ with a positive direct-axis current is clearly seen. The q-axis synchronous inductance of the studied PMSM as a function of $\mathrm{d}$ - and q-axis currents is shown in Fig. 5. The saturating effect by the d-axis current on the q-axis synchronous inductance is clearly visible.

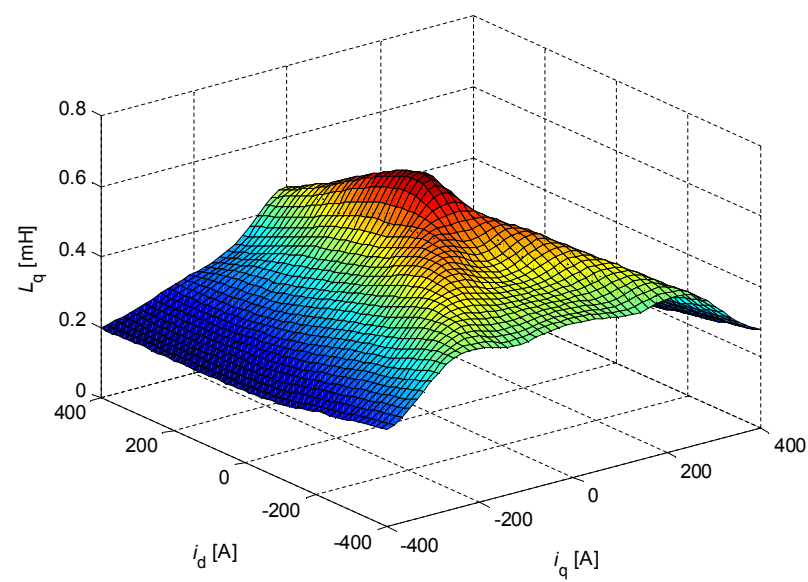

Fig. 5. Calculated quadrature-axis synchronous inductance incremental behavior as a function of direct- and quadrature-axis currents with $\Delta i_{\mathrm{q}}=20 \mathrm{~A}$.

\section{Load Characteristics}

The torque of the designed PMSM as a function of load angle is presented in Fig. 6. The torque was calculated at the rotation speed of $1000 \mathrm{rpm}$ and the magnet temperature of 80 ${ }^{\circ} \mathrm{C}$, that is, the remanent flux density of the PM material was 1.2 T. This corresponds to the line-to-line no-load voltage of $145.8 \mathrm{~V}$. In the calculations, a sinusoidal three-phase power source was used, and the line-to-line voltage was $165.4 \mathrm{~V}$. 


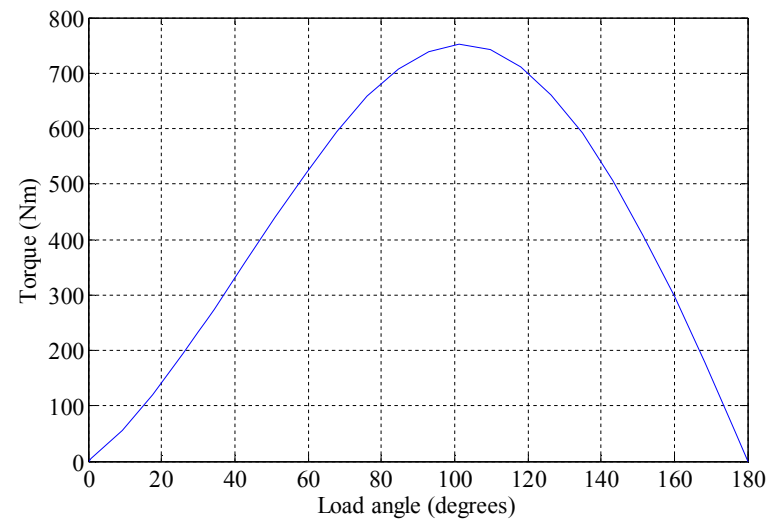

Fig. 6. Calculated motor torque as a function of load angle. The rotation speed was $1000 \mathrm{rpm}$, and the remanent flux density of the PM material was $1.2 \mathrm{~T}$. At the nominal torque $(240 \mathrm{Nm})$ the stator current was $102 \mathrm{~A}$.

As we can see in Fig. 6, the peak torque of the designed PMSM is $751 \mathrm{Nm}$ with the nominal line-to-line voltage, and it occurs at the load angle of 101 electrical degrees. Because the load angle at which the peak torque occurs is greater than 90 electrical degrees, the machine is clearly able to produce additional reluctance torque. A vector diagram of the designed PMSM in nominal torque operation at $1000 \mathrm{rpm}$ is depicted in Fig. 7. In Fig. 7, the power factor is $\cos \varphi=0.91\left(\varphi\right.$ is $\left.24^{\circ}\right)$, the load angle $\delta$ is $32^{\circ}$, and the current angle $\gamma$ is $98^{\circ} . \Psi_{\mathrm{PM}}=0.98$, $\Psi_{\mathrm{s}}=1.14$ p.u., $L_{\mathrm{q}} i_{\mathrm{q}}=0.63$ p.u., $L_{\mathrm{d}} i_{\mathrm{d}}=0.04$ p.u., $i_{\mathrm{s}}=1.05$ p.u., and $u_{\mathrm{s}}=1.14$ p.u. Stator resistance is neglected.

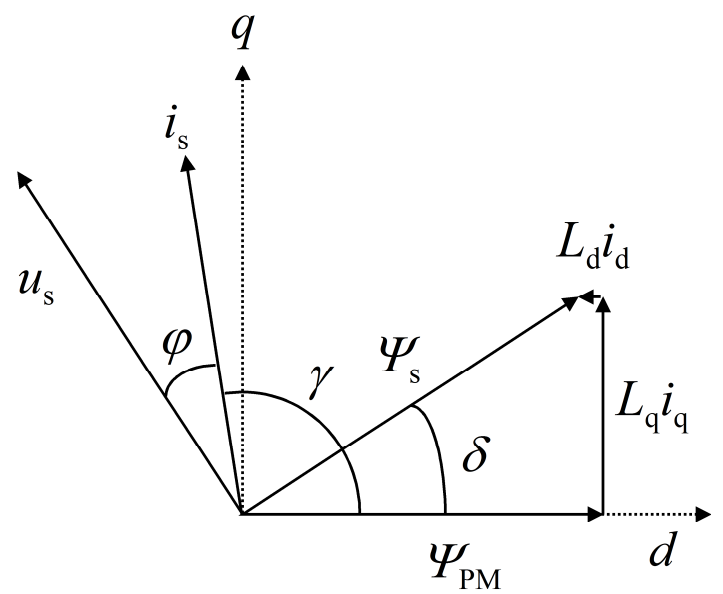

Fig. 7. Per unit vector presentation of the designed PMSM with the nominal current $(100 \mathrm{~A})$ and the nominal torque $(240 \mathrm{Nm})$. The rotation speed is 1000 rpm.

Let us next investigate the reluctance torque production capability of the designed PMSM as a function of load angle. As seen in Fig. 7, the load angle is defined as an angle between the permanent magnet and stator flux linkages, and it should not be confused with the current angle, which is the angle between the permanent magnet flux linkage and the stator current vector. In order to apply the FEM in the division of the total torque into the excitation and reluctance components, the frozen permeability method has to be applied [24]-[26]. The calculation has been made as follows: For each load angle, the instantaneous stator phase currents and the angular rotor position are recorded over one pole pair from the stable transient solution. These values are used to formulate a set of static solutions, one for each angular position. The static problem with a given angular position and phase currents is solved. Then, the reluctances in each element of the finite element mesh are recorded and used in a new static problem, which uses the same phase currents but the magnets are switched off, that is, they are replaced with a material having a relative permeability of 1.05 and a remanent flux density of 0 T. The torque computed from these static problems corresponds to the reluctance torque. For every load angle, the reluctance torque is computed as an average value over one pole pair. The reason why the calculation is extended over one pole pair is to take the magnetic circuit permeance variation into account. The calculated torque components as a function of load angle for the designed PMSM at the rotation speed of $1000 \mathrm{rpm}$ are shown in Fig. 8. In the calculation, the line-toline voltage of the sinusoidal three-phase power source was $165.4 \mathrm{~V}$.

As we can see in Fig. 8, the reluctance torque sign turns positive at a load angle of $\delta=22^{\circ}$. In practice this means that the current angle $\gamma$ exceeds $90^{\circ}$, and thus, a positive reluctance torque is produced. When the load angle is less than $22^{\circ}$, the current angle is below $90^{\circ}$, and the sign of the reluctance torque is negative. The reluctance torque production capability of the designed PMSM is very good, because in the breakdown torque point, the reluctance torque is one-third of the total torque.

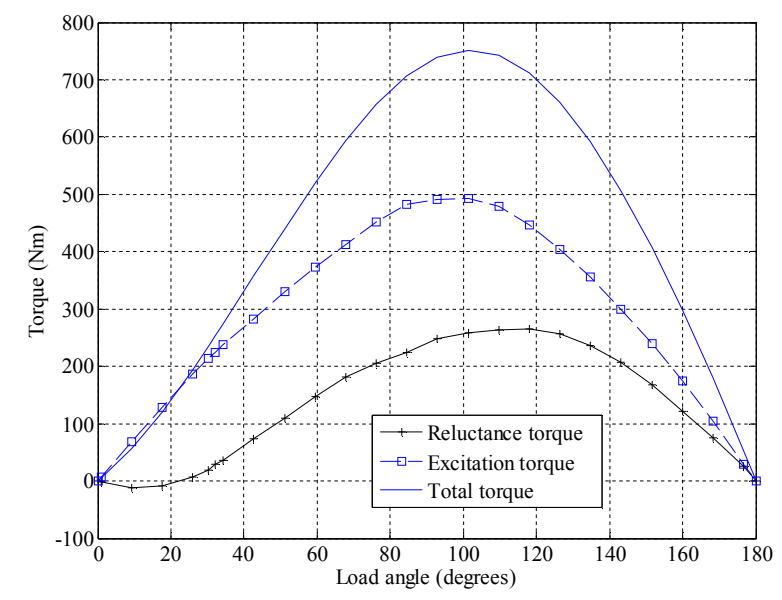

Fig. 8. Calculated torque components as a function of load angle.

\section{Field weakening performance}

As the battery voltage and charge decrease with the increasing load current, the field weakening operation inevitably occurs at higher rotational speeds. The field weakening performance of the designed PMSM can be demonstrated by calculating the machine performance at the rotation speed of $2000 \mathrm{rpm}$ and with the battery cut-off lineto-line voltage of $151.7 \mathrm{~V}$. At the rotation speed of $2000 \mathrm{rpm}$, the line-to-line no-load voltage with hot magnets is $291.8 \mathrm{~V}$, and thus, a demagnetizing $\mathrm{d}$-axis current is needed. The 
calculation results with the motor phase current and the torque as a function of load angle are illustrated in Fig. 9.

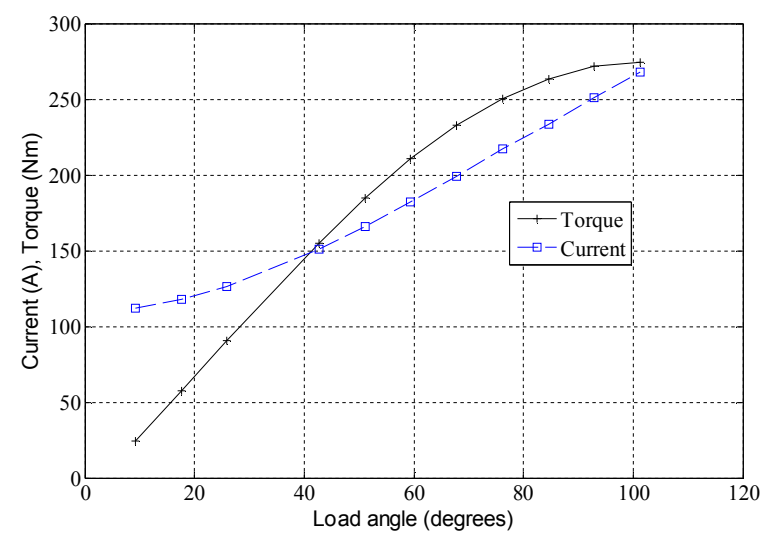

Fig. 9. Calculated motor torque and phase current as a function of load angle in the field weakening operation.

As it can be seen in Fig. 8, the designed PMSM is capable of nominal torque operation also in the field weakening.

\section{E. Current boost performance}

In order to reach the desired $800 \mathrm{Nm}$ peak torque, the stator flux linkage must be increased, that is, current and flux boosts are used. The calculated torque-current characteristics of the designed PMSM with the line-to-line voltages of $198.5 \mathrm{~V}$ and $246.8 \mathrm{~V}$ at the rotation speed of $1000 \mathrm{rpm}$ are presented in Fig. 10.

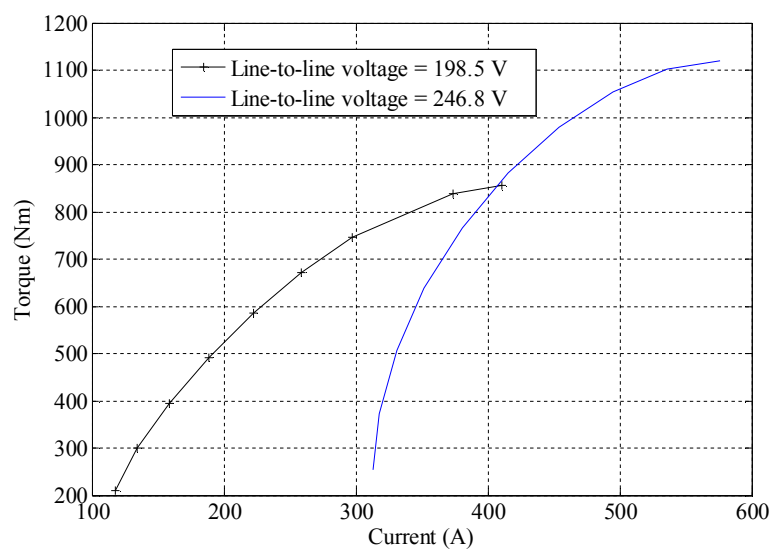

Fig. 10. Calculated torque-current characteristics of the designed PMSM with the line-to-line voltages of $198.5 \mathrm{~V}$ and $246.8 \mathrm{~V}$ at the rotation speed of 1000 rpm.

As we can see in Fig. 10, the peak torque is $855 \mathrm{Nm}$ and the corresponding phase current RMS value is $410.8 \mathrm{~A}$ when the line-to-line voltage is increased to $198.5 \mathrm{~V}$. The maximum torque of the machine at $1000 \mathrm{rpm}$ is reached when the stator line-to-line voltage is further increased to $246.8 \mathrm{~V}$. The maximum torque of the machine is $1120 \mathrm{Nm}$ and the required phase current RMS value is 576.3 A. Saturation of the magnetic circuit is clearly seen in Fig. 10. When the torque is at its maximum $(1120 \mathrm{Nm})$, the flux density in the stator tooth is $2.03 \mathrm{~T}$. At the $855 \mathrm{Nm}$ torque, the flux density in the stator tooth is 1.74. At the nominal torque $(240 \mathrm{Nm})$, the corresponding flux density value is $1.48 \mathrm{~T}$.

\section{F. Efficiency and loss distribution}

The calculated efficiencies of the designed PMSM at the rotational speeds of $1000 \mathrm{rpm}$ and $2000 \mathrm{rpm}$ as a function of output power are illustrated in Fig. 11. At the rotation speed of $2000 \mathrm{rpm}$, a full battery was assumed, and the corresponding line-to-line voltage was a constant value of $293.5 \mathrm{~V}$. At the rotation speed of $1000 \mathrm{rpm}$, the line-to-line voltage was 165.4 $\mathrm{V}$ at the output power less than $77 \mathrm{~kW}$. At higher output powers, the line-to-line voltage was increased gradually to $246.8 \mathrm{~V}$.

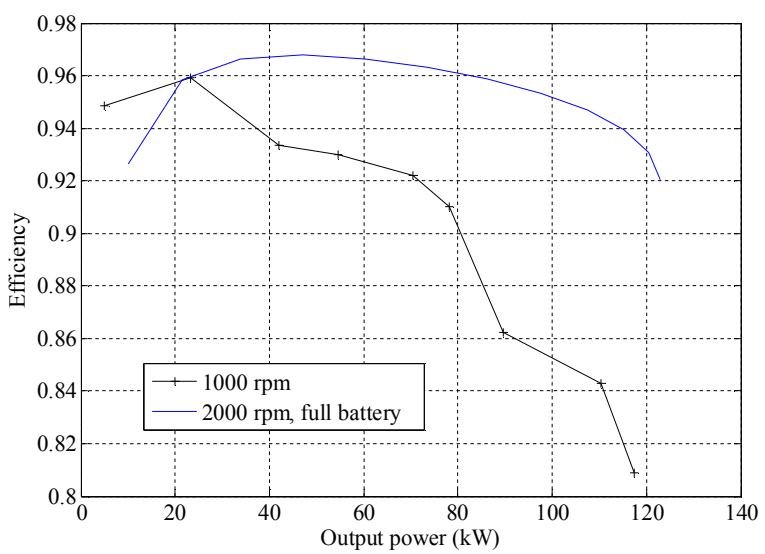

Fig. 11. Calculated efficiencies of the designed PMSM at the rotation speeds of $1000 \mathrm{rpm}$ and $2000 \mathrm{rpm}$ as a function of output power.

At $1000 \mathrm{rpm}$, the maximum efficiency (0.96) is reached at the nominal power of $25 \mathrm{~kW}$. At higher output power values, the efficiency decreases mostly as a result of increased copper losses. At $2000 \mathrm{rpm}$, the motor efficiency remains high regardless of the output power. The calculated loss distributions as a function of output power at rotation speeds of $2000 \mathrm{rpm}$ and $1000 \mathrm{rpm}$ are illustrated in Figs. 12 and 13. The stator copper losses are calculated by using the measured phase resistances and the calculated phase currents. The eddycurrent losses in permanent magnets are obtained by treating them as short-circuited solid conductors in the FEA. Stator iron loss calculation is carried out by using a loss-surface model implemented in the Flux2D/3D software package. The rotor iron loss is neglected in Figs. 12 and 13 because of its low value (less than $25 \mathrm{~W}$ ). The total losses also include analytically calculated friction losses.

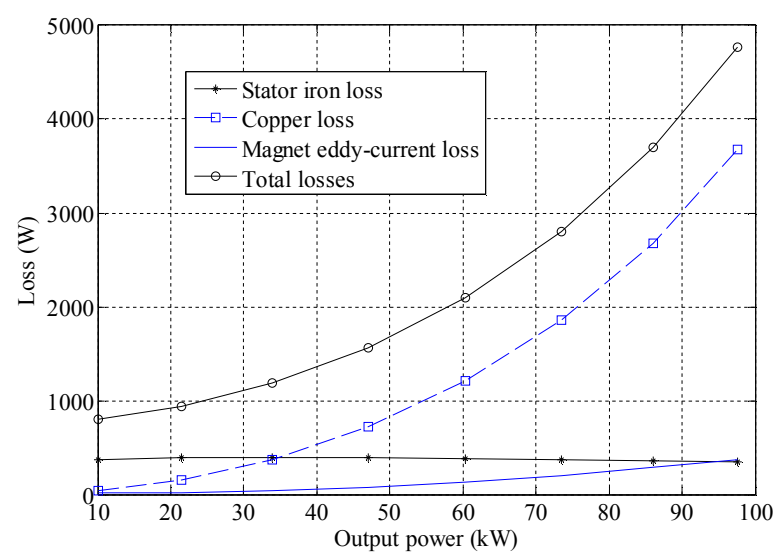


Fig. 12. Calculated loss distribution of the designed PMSM at the rotation speed of $2000 \mathrm{rpm}$ as a function of output power. In the calculations, the lineto-line voltage was $293.5 \mathrm{~V}$.

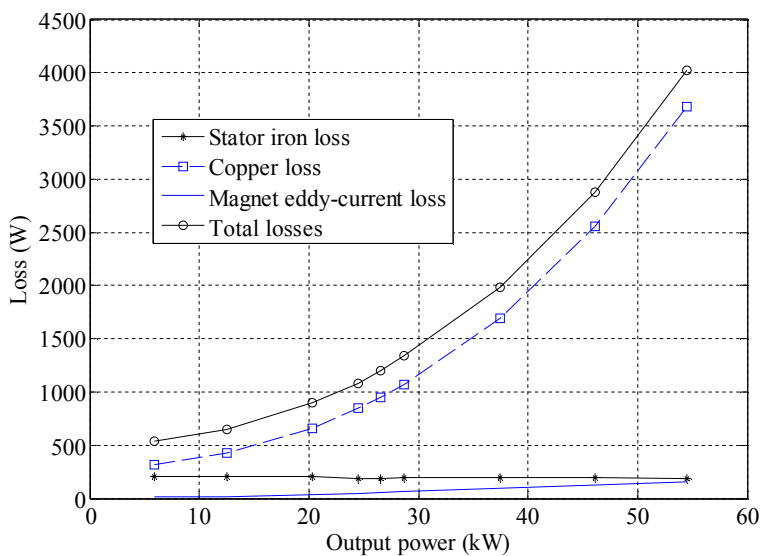

Fig. 13. Calculated loss distribution of the designed PMSM at the rotation speed of $1000 \mathrm{rpm}$ as a function of output power. In the calculations, the lineto-line voltage was $165.4 \mathrm{~V}$.

As it is seen in Figs. 12 and 13, copper losses dominate regardless of the rotation speed.

\section{MEASUREMENTS}

Four PMSMs were manufactured in cooperation with Lappeenranta University of Technology (LUT) and Axco Motors Oy. The assembly of the rotor inside the stator is shown in Fig. 14. The designed PMSMs were tested at LUT using a test setup consisting of a frequency converter by Vacon Oy, a three-phase $355 \mathrm{~kW}$ ABB induction machine acting as a load machine, a Magtroll $2000 \mathrm{Nm}$ torque meter, a Yokogawa PZ-4000 power analyzer, and a Fluke thermometer unit for PT-100 temperature elements.

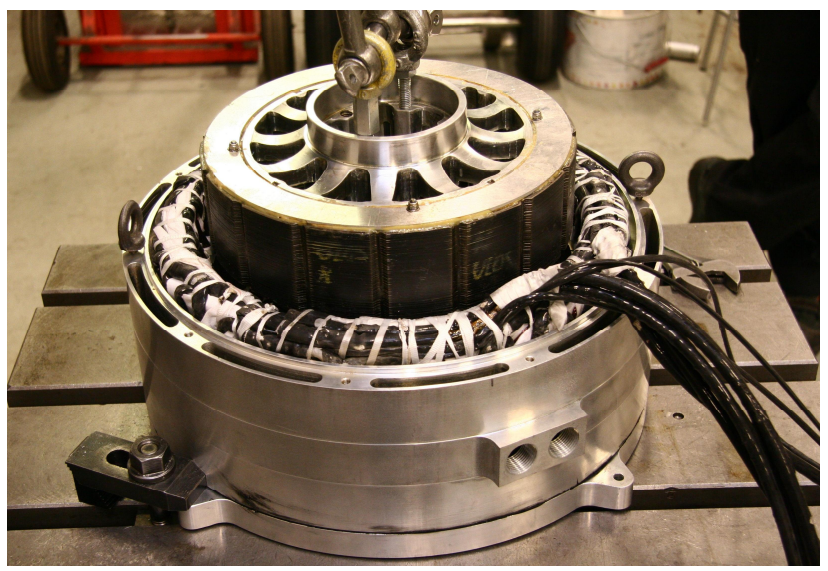

Fig. 14. Designed PMSM in assembly.

The machine torque as a function of rotation speed when the machine current was kept at a constant value of $100 \mathrm{~A}$ is presented in Fig. 15. The torque decay is approximately 7 percent in the torque output when comparing with the $300 \mathrm{rpm}$ and $2000 \mathrm{rpm}$ values at the nominal current. The drop is caused by a decrease in the back EMF voltage resulting from the increasing magnet temperature.

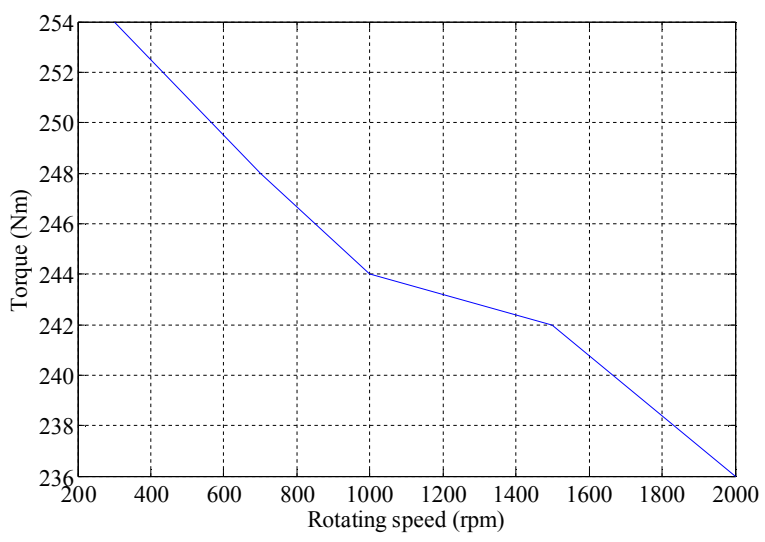

Fig. 15. Measured machine torque as a function of rotation speed when the machine current is kept at a nominal value of $100 \mathrm{~A}$.

Measured efficiency as a function of rotation speed at the nominal current $(100 \mathrm{~A})$ and $60 \mathrm{~A}$ current are presented in Fig. 16. As we can see in Fig. 16, the machine efficiency is higher at low stator current values. The measured efficiencies are slightly lower than the measured ones.

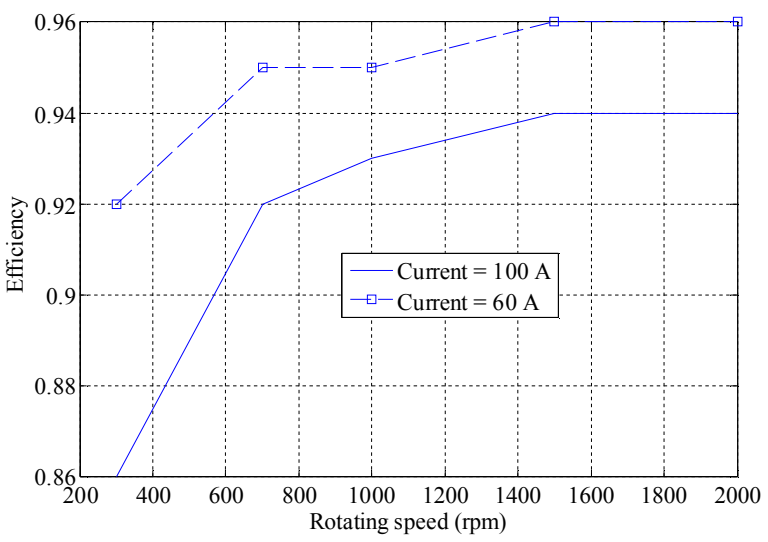

Fig. 16. Measured machine efficiency as a function of rotation speed at two stator phase current values, $60 \mathrm{~A}$ and $100 \mathrm{~A}$, respectively.

In order to test the cooling capability of the liquid-cooled frame, the end-winding steady-state temperature of the machine was measured. To simulate a moving machine cooling arrangement, the cooling of the machine was arranged with an aluminum radiator and a 12 volt electric water pump. The radiator was exposed to a forced cooling with an axial fan. In this test, the cooling water mass flow rate was $0.12 \mathrm{~kg} / \mathrm{s}$ and the water inlet temperature was $20^{\circ} \mathrm{C}$. The measured endwinding steady-state temperatures as a function of rotation speed at the nominal current are shown in Fig. 17. 


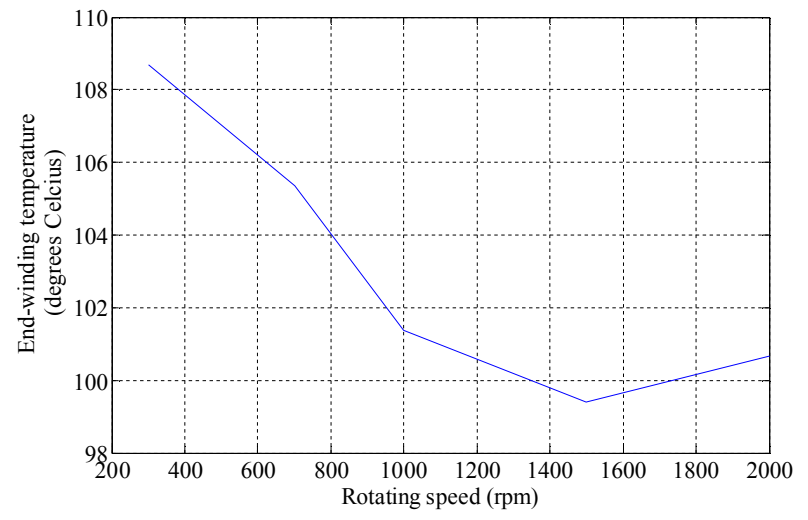

Fig. 17. Measured end-winding temperature as a function of rotation speed when the machine current is kept at a nominal value of $100 \mathrm{~A}$.

The designed PMSMs were installed into an Electric RaceAbout (E-RA) full electric sports car shown in Fig. 18. The E-RA made a new road-legal electric vehicle lap record on Nürburgring Nordschleife in September 2011. The German race driver Ralf Kelleners needed only 8 minutes and 42.72 seconds on E-RA to complete a full lap of $20.832 \mathrm{~km}$. The average speed for the lap was $142 \mathrm{~km} / \mathrm{h}$ and the top speed was $238 \mathrm{~km} / \mathrm{h}$. Later on during testing, Kelleners reached an even more impressive maximum speed of $244 \mathrm{~km} / \mathrm{h}$. For the complete record lap, the E-RA consumed $25.6 \mathrm{kWh}$, measured as energy taken from the grid to recharge the battery.

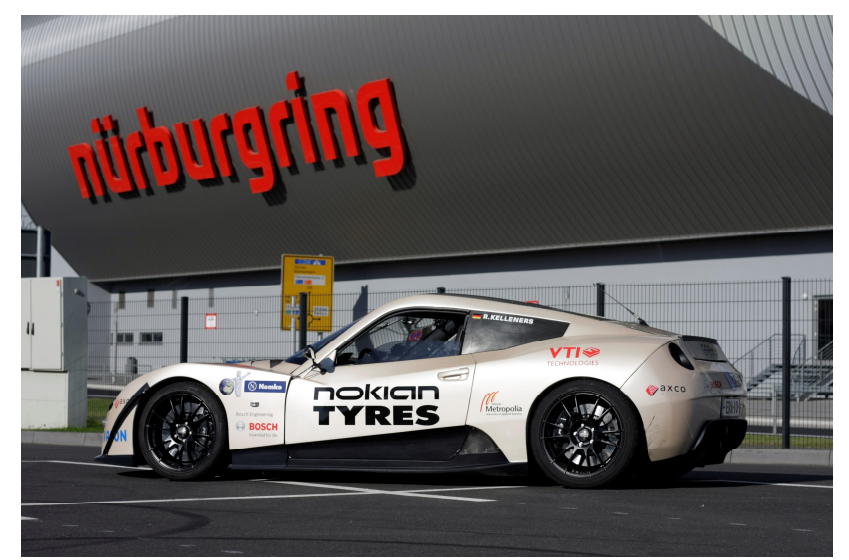

Fig. 18. Full electric sports car Electric RaceAbout.

The measured Nürburgring Nordschleife track data from the right rear machine are presented in Figs. 19-23. Measured track data are seldom published, although they could be very valuable to motor designers working in the field of electric vehicles. Figs. 19-22 also illustrate the fact that the machine has no specific operating point. The measured motor torque is shown in Fig. 19. The peak torque is approximately $600 \mathrm{Nm}$. As seen in Fig. 20, the maximum rotation speed of the motor is $1987 \mathrm{rpm}$. The measured stator phase current and line-toline voltage are illustrated in Figs. 21 and 22. Fig. 23 presents the measured end-winding temperature of the motor.

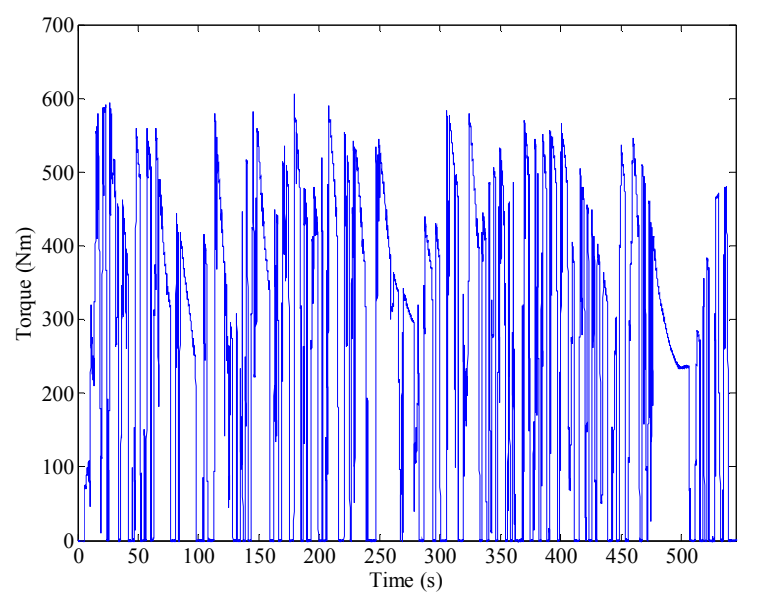

Fig. 19. Measured torque of the motor as a function of time.

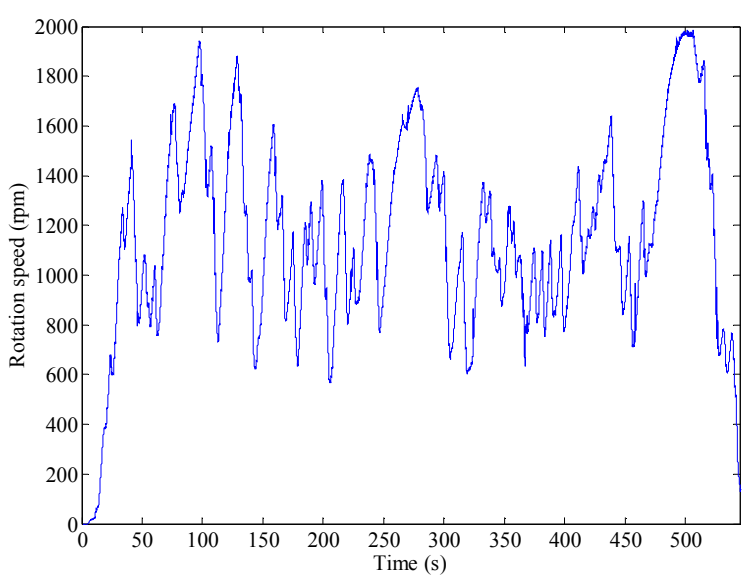

Fig. 20. Motor rotation speed as a function of time.

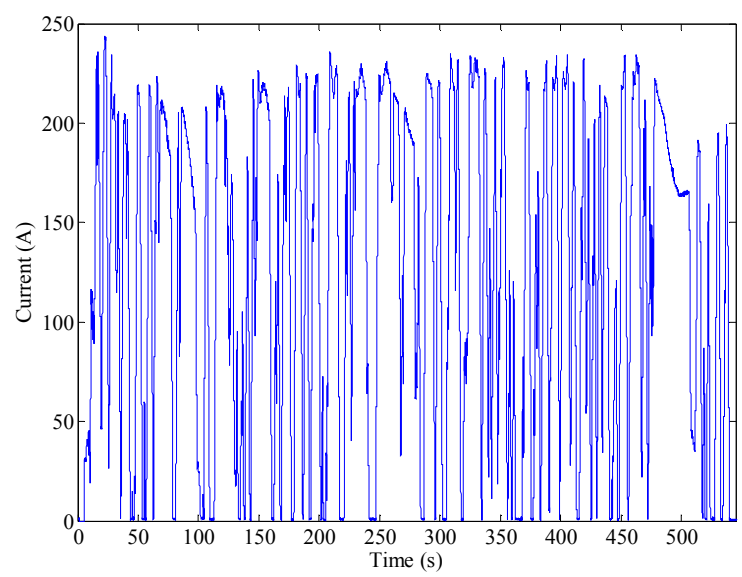

Fig. 21. Measured phase current of the motor as a function of time. 


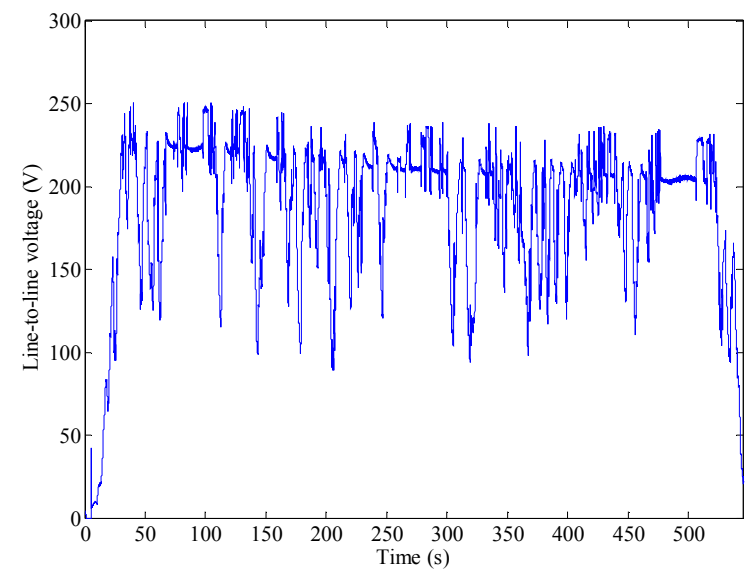

Fig. 22. Measured line-to-line voltage of the motor as a function of time. The line-to-line voltage decrease is due to a decrease in the battery voltage.

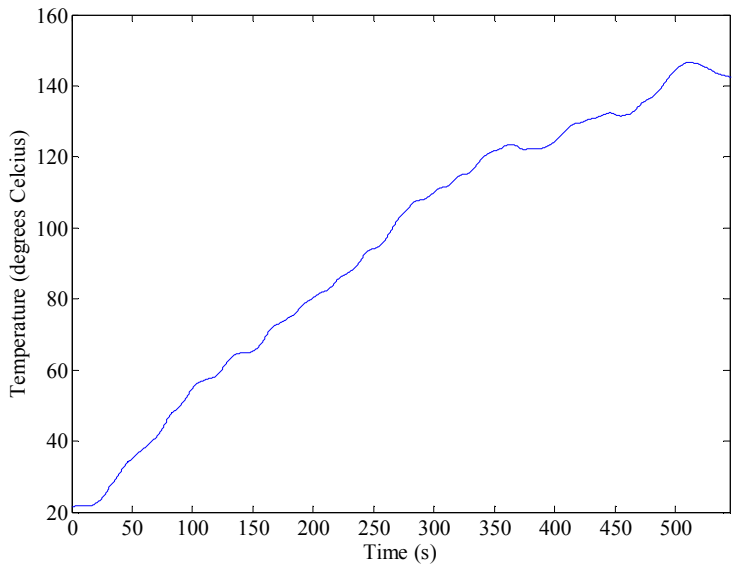

Fig. 23. Measured end-winding temperature of the motor as a function of time.

\section{CONCLUSIONS}

The design process of direct-driven PMSMs for a full electric sports car was presented. Because the maximum torque is needed in acceleration at a low rotation speed, the magnetic circuit of the stator was dimensioned loose enough to avoid excessive saturation when current boost is used. The performance of the designed PMSM was evaluated by applying the two-dimensional finite element method. The effect of cross-saturation on the direct- and quadrature-axis synchronous inductances was illustrated. It was shown that the reluctance torque production capability of the motor is very good. The efficiency and loss distribution were analyzed, and it was shown that the major loss component of the studied motor is stator copper losses. The PMSM can produce nominal torque with the nominal current in a wide speed range. The calculation results were compared with the practical measurements, and a good correlation was found. Furthermore, the measured race track data from a road-legal electric vehicle lap record on Nürburgring Nordschleife in September 2011 were presented.

\section{REFERENCES}

[1] C. C. Chan, "The State of the Art of Electric and Hybrid Vehicles," IEEE Proc., vol. 90, no. 3, February 2002, pp. 247-275.

[2] K. T. Chau, C. C. Chan, C. Liu, "Overview of Permanent-Magnet Brushless Drives for Electric and Hybrid Electric Vehicles," IEEE Trans. Ind. Electron., vol. 55, no. 6, June 2008, pp. 2264-2257.

[3] C. C. Chan, A. Bouscayrol, K. Chen, "Electric, Hybrid, and Fuel Cell Vehicles: Architectures and Modeling," IEEE Trans. Veh. Technol., vol. 59, no. 2, February 2010, pp. 589-598.

[4] N. Mutoh, "Driving and Braking Torque Distribution Methods for Frontand Rear-Wheel-Independent Drive-Type Electric Vehicles on Roads With Low Friction Coefficient," IEEE Trans. Ind. Electron., vol. 59, no. 10, October 2012, pp. 3919-3933.

[5] Z. Q. Zhu, D. Howe, "Electrical Machines and Drives for Electric, Hybrid, and Fuel Cell Vehicles," IEEE Proc., vol. 95, no. 4, April 2007 pp. 746-765.

[6] D. G. Dorrell, A. M. Knight, M. Popescu, "Performance Improvement in High-Performance Brushless Rare-Earth Magnet Motors for Hybrid Vehicles by Use of High Flux-Density Steel," IEEE Trans. Magn., vol. 47, no. 10, October 2011, pp. 3016-3019.

[7] A. Wang, Y. Jia, W. L. Soong, "Comparison of Five Topologies for an Interior Permanent-Magnet Machine for a Hybrid Electric Vehicle," IEEE Trans. Magn., vol. 47, no. 10, October 2011, pp. 3606-3609.

[8] G. Pellegrino, A. Vagati, P. Guglielmi, B. Boazzo, "Performance Comparison Between Surface-Mounted and Interior PM Motor Drives for Electric Vehicle Application," IEEE Trans. Ind. Electron., vol. 59, no. 2, February 2012, pp. 803-811.

[9] P. H. Nguyen, E. Hoang, M. Gabsi, "Performance Synthesis of Permanent-Magnet Synchronous Machines During the Driving Cycle of a Hybrid Electric Vehicle," IEEE Trans. Veh. Technol., vol. 60, no. 5, June 2011, pp. 1991-1998.

[10] K. I. Laskaris, A. G. Kladas, "Internal Permanent Magnet Motor Design for Electric Vehicle Drive," IEEE Trans. Ind. Electron., vol. 57, no. 1, January 2010, pp. 138-145.

[11] A. EL-Refaie, "Fractional-Slot Concentrated-Windings Synchronous Permanent Magnet Machines: Opportunities and Challenges," IEEE Trans. Ind. Electron., vol. 57, no. 1, January 2010, pp. 107-121.

[12] P. B. Reddy, A. M. El-Refaie, K-K. huh, J. K. Tangudu, T. M. Jahns," Comparison of Interior and Surface PM Machines Equipped With Fractional-Slot Concentrated Windings for Hybrid Traction Applications," IEEE Trans.Energy Convers., vol. 27, no. 3, September 2012, pp. 593-602.

[13] G. Y. Sizov, D. M. Ionel, N. A. O. Demerdash," Modeling and Parametric Design of Permanent-Magnet AC Machines Using Computationally Efficient Finite-Element Analysis," IEEE Trans. Ind. Electron., vol. 59, no. 6, June 2012, pp. 2403-2413.

[14] K. I. Laskaris, A. G. Kladas," Optimal Power Utilization by Adjusting Torque Boost and Field Weakening Operation in Permanent Magnet Traction Motors," IEEE Trans. Energy Convers., Vol. 27, no. 3, September 2012, pp. 615-623.

[15] J. Nerg, M. Rilla, V. Ruuskanen, J. Pyrhönen, S. Ruotsalainen,” Design of Direct-Driven Permanent Magnet Synchronous Motors for an Electric Sports Car," in Proc. XX International Conference on Electrical Machines, 2012, Marseilles, France.

[16] Electric Raceabout [Online]. Available : http://www.raceabout.fi/era/

[17] I. Boldea, L. Tutelea, C. I. Pitic, "PM-Assisted Reluctance Synchronous Motor/Generator (PM-RSM) for Mild Hybrid Vehicles: Electromagnetic Design," IEEE Trans. Ind. Appl., vol. 40, no. 2, March/April 2004, pp. 492-498.

[18] M. Barcaro, N. Bianchi, F. Magnussen," Permanent-Magnet Optimization in Permanent-Magnet-Assisted Synchronous Reluctance Motor for a Wide Constant-Power Speed Range," IEEE Trans. Ind. Electron., vol. 59, no. 6, June 2012, pp. 2495-2502.

[19] F. Parasiliti, M. Villani, S. Lucidi, F. Rinaldi," Finite-Element-Based Multiobjective Design Optimizatio Procedure of Interior Permanent Magnet Synchronous Motors for Wide Constant-Power Region Operation," IEEE Trans. Ind. Electron., vol. 59, no. 6, June 2012, pp. 2503-2514.

[20] J. Pyrhönen, V. Ruuskanen, J. Nerg, J. Puranen, H. Jussila, "PermanentMagnet Length Effects in AC Machines," IEEE Trans. Magn., vol. 46, no. 10 , October 2010 , pp. 3783-3789.

[21] V. Ruuskanen, J. Nerg, J. Pyrhönen, "Effect of Lamination Stack Ends and Radial Cooling Channels on No-Load Voltage and Inductances of 
Permanent-Magnet Synchronous Machines," IEEE Trans. Magn., vol. 47, no. 11, October 2011, pp. 4643-4649.

[22] G. Pellegrino, E. Armando, P. Guglielmi, ”Direct-Flux Vector Control of IPM Motors Drives in the Maximum Torque Per Voltage Speed Range," IEEE Trans. Ind. Electron., vol. 59, no. 10, October 2012, pp. 3780-3788.

[23] B. Štumberger, G. Štumberger, D. Dolinar, A. Hamler, M. Trlep, "Evaluation of Saturation and Cross-Magnetization Effects in Interior Permanent-Magnet Synchronous Motor," IEEE Trans. Ind. Appl., vol. 39, no. 5, September/October 2003, pp. 1264-1271.

[24] N. Bianchi, S. Bolognani, "Magnetic Models of Saturated Interior Permanent Magnet Motors Based on Finite Element Analysis," in Proc. $33^{\text {rd }}$ IAS Annu. Meeting, October 1998, St. Louis, Missouri, USA, pp 27-34.

[25] J. A. Walker, D. G. Dorrell, C. Cossar, "Flux-Linkage Calculation in Permanent-Magnet Motors Using the Frozen Permeabilities Method," IEEE Trans. Magn., vol 41, no. 10, pp. 3946-3948, October 2005.

[26] D. G. Dorrell, A. M. Knight, L. Evans, M. Popescu, "Analysis and Design Techniques Applied to Hybrid Vehicle Drive Machines Assessment of Alternative IPM and Induction Motor Topologies," IEEE Trans. Ind. Electron., vol. 59, no. 10, October 2012, pp. 3690-3699.

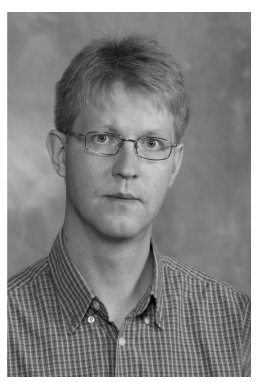

Janne Nerg (M'99-SM'12) became a Member (M) of IEEE in 1999 and a Senior Member (SM) in 2012. He received the M. Sc. Degree in electrical engineering, the Licentiate of Science (Technology) degree, and the D. Sc. (Technology) degree from Lappeenranta University of Technology (LUT), Lappeenranta, Finland, in 1996, 1998, and 2000 , respectively.

He is currently an Associate Professor in the Department of Electrical Engineering at LUT. His research interests are in the field of electrical machines and drives, especially electromagnetic and thermal modeling and design of electromagnetic devices.

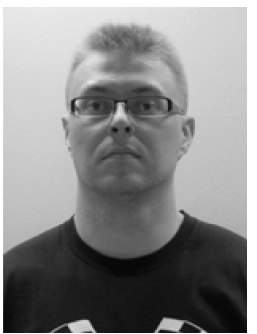

Marko Rilla received the M. Sc Degree in electrical engineering and the D. Sc. (Technology) degree from Lappeenranta University of Technology (LUT), Lappeenranta, Finland, in 2006 and 2012, respectively.

$\mathrm{He}$ is currently a design engineer at Visedo Oy, Finland. His technical interests include modeling and optimization of electrical machines and drives.

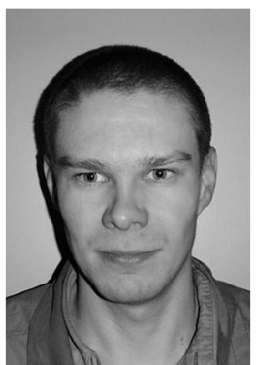

Vesa Ruuskanen received the M. Sc. Degree in electrical engineering and $\mathrm{D}$. Sc. (Technology) degree from Lappeenranta University of Technology (LUT), Lappeenranta, Finland, in 2007 and 2011, respectively.

$\mathrm{He}$ is currently a post-doctoral researcher in the Department of Electrical Engineering at LUT. His research interests are in the field of permanent magnet machines and drives, especially direct driven wind generators.

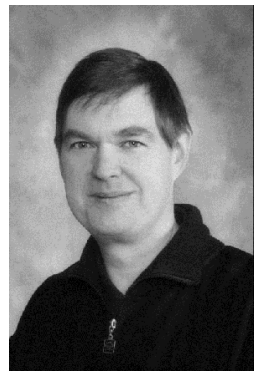

Juha Pyrhönen (M’06) became a Member (M) of IEEE in 2006. He received the M.Sc. degree in electrical engineering, the Licentiate of Science (Technology) degree, and D. Sc. degree (Technology) from Lappeenranta University of Technology (LUT), Lappeenranta, Finland, in 1982, 1989 and 1991, respectively.

He has served as Associate Professor in Electric Engineering at LUT starting 1993 and has been appointed Professor in Electrical Machines and Drives in 1997. He worked as the Head of the Department of Electrical Engineering from 1998 to 2006 . He is active in the research on and development of electric motors and electric drives.

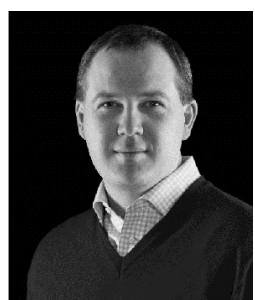

Sami Ruotsalainen received the M. Sc Degree in Automotive Engineering from Helsinki University of Technology in 1998.

$\mathrm{He}$ is currently senior lecturer at Helsinki Metropolia University of Applied Sciences in Finland where he is teaching automotive electrical and systems engineering and developing electric vehicles. 
12-TIE-1926.R1 